\title{
Clinical Variants of Primary Sclerosing Cholangitis: When Does Liver Biopsy Make the Diagnosis?
}

\author{
Annarosa Floreani \\ Dept. of Surgical and Gastroenterological Sciences, \\ University of Padova, \\ Italy
}

\section{Introduction}

Primary sclerosing cholangitis (PSC) is a cholestatic disorder of unknown aetiology, characterized by inflammation and obliterative fibrosis involving the intrahepatic, extrahepatic bile ducts or both (1). It predominates among men and is frequently associated with inflammatory bowel diseases, particularly with ulcerative cholitis. Although there are animal models of PSC, pathogenesis is still poorly characterized (2). The target of the immune reaction is the medium and large bile ducts. Sensitized bile ducts are damaged by different immune cells that are activated in the gastro-intestinal tract and lymph nodes. Cholangiocytes become activated to express adhesion molecules, inflammatory and profibrogenic cytokines, together growth factors that stimulate the production of fibrous tissue.

The diagnosis of PSC is based in patients who present with an alteration of cholestatic enzymes on the basis of magnetic resonance (MRN) cholangiography or direct cholangiography (ERCP) which show the typical changes of the biliary tree with multifocal strictures and segmental dilatation (3).

PSC, however, is a heterogeneous disease characterized by at least four variants:

1. "Classical" PSC (involving the intrahepatic, extrahepatic biliary tree or both)

2. Small-duct PSC

3. PSC/autoimmune hepatitis (AIH) overlap syndrome

4. IgG4 associated cholangitis (IAC)

\section{2. "Classical" PSC}

The diagnostic approach of this variant has been changed over the last years, due to the amelioration of radiological techniques. The gold standard is the cholangiography performed with MNR or ERCP, showing the typical changes of the biliary tree (3). A recent meta-analysis including 6 manuscripts for a total 456 patients, have shown that MRN has a $86 \%$ sensitivity and $94 \%$ specificity for detecting PSC (4). The American Association for the Study of Liver Disease (AASLD) recommend against routine liver biopsy for the diagnosis of PSC in patients with typical cholangiographic findings (3). A retrospective study performed at the Mayo Clinic 
in 138 patients with PSC showed that liver biopsy did not add important clinical information, with the exception of a small group of patients $(1.3 \%)$ in whom liver histology was fundamental for the diagnosis of the overlap syndrome with $\mathrm{AIH}$ (5).

In 2002 an international group reported on the prognostic of cholangiographic abnormalities generating a scoring model based on the assumption that both intra- and extra-hepatic lesions of the biliary tree would reflect the disease severity (6). More recently, this model was validated in a large cohort of patients with PSC providing a nomogram which may be used to predict medium- and long-term prognosis in individual patients with PSC (7). Indeed, the imaging techniques have the objective to rule out secondary cholangitis and to evaluate cholangiography findings which may be associated with cholangiocarcinoma.

\section{Small-duct PSC}

This is a variant disease characterized by typical cholestatic and histological features of PSC but normal bile ducts on cholangiography (8). It is not clear if small-duct PSC represents an early onset of the disease or a different entity. However, studies addressing the natural history of this variant have shown a better prognosis of small-duct PSC than the large duct PSC. In particular, two multicentre studies have been published so far. The first one included 33 patients with small-duct PSC and 260 patients with large-duct PSC evaluated in Oxford and Oslo with a median follow-up of 106 vs 105 months respectively (9). More recently, another European and US study included 83 patients with small-duct PSC and 166 patients with large-duct PSC with a median follow-up of 11 years (8). Both studies report similar conclusions, showing a statistically significant better prognosis for small-duct PSC than large-duct PSC patients.

Liver biopsy is mandatory for the diagnosis of small-duct PSC in patients with a normal ERCP or MRN (3). Periductal concentric ("onion-skin") fibrosis is the classical finding of PSC, unless unspecific histological diagnosis include PSC/AIH overlap syndrome, and a number of secondary causes of sclerosing cholangitis including eosinophilic cholangitis, histiocytosis $\mathrm{X}$, ischemic cholangitis, mastcell cholangiopathy, and bacterial cholangitis.

\section{PSC/AIH overlap syndrome}

This is a disorder mainly described in children and young adults (10-12). Its characteristics include clinical, biochemical, and histologic features typical of PSC. Gregorio et al (10) identified a $49 \%$ prevalence of PSC/ AIH overlap syndrome among AIH paediatric patients, whereas in adult series it seems to be quite rare. Diagnosis of an overlap syndrome by use of the modified AIH score ranges from 1.4 to 12.5-17\% (Table 1, ref. 11, 13-16). The reason of the higher rate in Italy may be explained with the inclusion in our series of a number of patients deriving from a cohort of paediatric series.

More recently, the King's group in London defines PSC with strong autoimmune features in children as autoimmune sclerosing cholangitis (ASC)(17). In contrast with the male overrepresentation in adults, over $50 \%$ of paediatric patients with ASC are girls (17). In our experience, patients with $\mathrm{PSC} / \mathrm{AIH}$ overlap syndrome are significantly younger at presentation and exhibit significantly higher serum levels of transaminases and IgG than the classical PSC group (15). Association with IBD is more common in the group with "classical" PSC than PSC/AIH overlap syndrome group $(46.4 \%$ vs $20 \%, p<0.01)$. As expected, non organ-specific autoantibodies which represent the hallmarks of autoimmunity 
are positive in nearly all patients with PSC/AIH overlap syndrome. Some $50 \%$ of the patients have atypical perinuclear antineutrophil cytoplasmic antibodies (p-ANCAs). In our experience the cumulative probability of survival at 20 years was higher in PSC/AIH overlap syndrome than in the "classical" PSC $(87.5 \%$ vs $73.6 \%)$ but the difference was not statistically significant (16).

\begin{tabular}{|l|c|c|c|}
\hline \multicolumn{1}{|c|}{ Author } & Country & n. of PSC patients & \% with overlap \\
\hline Van Buuren, $2000^{13}$ & Netherlands & 113 & $8 \%$ \\
\hline Kaya, $2000^{14}$ & USA & 211 & $1.4 \%$ \\
\hline Floreani, $2000^{15}$ & Italy & 41 & $17 \%$ \\
\hline Antoniazzi, $2010^{16}$ & Italy & 79 & $12.6 \%$ \\
\hline Al-Chalaby, $2008^{11}$ & UK & 211 & $6.1 \%$ \\
\hline
\end{tabular}

Table 1. Diagnosis of AIH/PSC overlap by use of the modified AIH score

Liver histology is mandatory for the diagnosis of PSC/AIH overlap syndrome. The main features include: piecemeal necrosis, lymphocyte rosetting, and moderate or severe periportal or periseptal inflammation (15).

The EASL guidelines recommend a medical treatment for PSC/AIH overlap syndrome with ursodeoxycholic acid and immunosuppressive therapy, but is not evidence-based due to lack of adequate studies (18).

In a retrospective study concentrating on the histological features of PSC in children, Batres et al report that $45 \%$ of 20 patients had variable degrees of interface hepatitis at diagnosis (19).

\section{IgG4-associated sclerosing cholangitis}

This is a distinct form of PSC recently described in the literature, of unknown aetiology and characterized by elevated serum IgG4 and infiltration of IgG4-positive plasma cells in bile ducts and liver tissue (20). Since the first observations, it became evident that IAC was highly associated to autoimmune pancreatitis (AIP) which represents a distinct form of chronic pancreatitis occasionally observed in association with Sjogren's syndrome, primary biliary cirrhosis, Crohn's disease, ulcerative cholitis or other immune-mediated disorders (21).

Kamisawa et al. reported that tissue infiltration with abundant IgG4-positive cells was a characteristic feature not only of AIP but also of other organs involved in AIP (22). The clinical profile of IAC include: 1) older age; 2) male gender (in up to $85 \%$ of cases); 3 ) presentation with obstructive jaundice; 4) association with AIP in more than $90 \%$ of cases; 6 ) abundant IgG4 infiltrate in biopsy duct specimens; 7) normalization of liver enzymes with steroids (20). A recent study found serum IgG4 in 9\% in a cohort of 127 patients with PSC (23). In comparison to patients with PSC and normal levels of IgG4, the former group had significantly higher levels of alkaline phosphatise and bilirubin, in addition to higher Mayo risk prognostic score (23). Preliminary data suggest that the immunopathogenesis of IAC differs from other immune-mediated cholestatic liver disease in that $\mathrm{T}$ helper 2 and $\mathrm{T}$ regulatory cytokines were markedly overexpressed in IAC patients (24). Being apparently different from PSC and similar to AIP, sclerosing cholangitis with and without AIP shows a clinical response to steroid therapy (25). When intra-pancreatic stenosis is detected with imaging procedures, pancreatic cancer shoul be ruled out. For the diagnosis of Ig4-positive AIC a liver biopsy with IgG4 immunostaining is needed (26). If stenosis is demonstrated in the hepatic hilar region, cholangiocarcinoma should be discriminated by imaging techniques and bile duct biopsy (26). 


\section{Pathology findings}

Liver biopsy is recommended for the diagnosis of small-duct PSC, AIH/PSC overlap syndrome and IAC. Bile duct biopsy is mandatory to rule out cholangiocarcinoma in any form of PSC. Cholangiocarcinoma should be suspected in case of dominant stenosis (common bile duct $\leq 1.5 \mathrm{~mm}$ in diameter or hepatic duct $\leq 1 \mathrm{~mm}$ )(27) or in case of "tumour" appearance in the hilar region (28).

\section{Bile duct biopsy}

The common characteristic in PSC is the fibro-inflammatory involvement of large ducts and the infiltration of lymphocytes in small ducts together with the "onion-like" fibrosis surrounding the small intra-hepatic ducts. The IAC type shows peculiar characteristics with dense infiltration of lymphocytes and IgG4-positive plasma cells with extensive fibrosis and obliterative phlebitis (29). In classical PSC the fibrosis is dense and older, whereas in IgG4IAC the entire bile duct walls and periductular tissue are affected. Ghezale et al (20) reported positive and abundant IgG4 immunostaining (>10 IgG4-positive cell/HPF) of bile duct biopsy specimens of bile duct in $88 \%$ of patients. The IgG4 immunostaining needs further clarification, however; in fact, a recent study by Zhang et al (30) revealed that $23 \%$ of 98 explanted livers with PSC had periductal infiltration with abundant IgG4-positive plasma cells (>10/HPF) in the hilar area.

In the small-duct PSC large bile duct are normal and only changes in the interlobular bile ducts are seen, resulting in "normal" findings at cholangiography (31).

In the AIH/PSC overlap syndrome bile duct biopsy shows similar characteristics than "classical" PSC.

The main histopathological findings are summarized in the table 2.

\begin{tabular}{|l|c|c|c|c|}
\hline & $\begin{array}{c}\text { Classical } \\
\text { PSC }\end{array}$ & $\begin{array}{c}\text { Small duct } \\
\text { PSC }\end{array}$ & $\begin{array}{c}\text { AIH/PSC } \\
\text { overlap }\end{array}$ & IgG4-ISC \\
\hline $\begin{array}{l}\text { LARGE BILE } \\
\text { DUCTS }\end{array}$ & $\begin{array}{c}\text { Luminal side } \\
\text { including } \\
\text { cholangiocytes }\end{array}$ & Normal & $\begin{array}{c}\text { Similar to } \\
\text { classical PSC }\end{array}$ & $\begin{array}{c}\text { Whole bile duct walls } \\
\text { and periductal tissue }\end{array}$ \\
\hline $\begin{array}{l}\text { Inflammatory } \\
\text { Infiltrate }\end{array}$ & Mild & Absent & Mild & $\begin{array}{c}\text { Abundant infiltrate of } \\
\text { lymphocytes and IgG4- } \\
\text { positive plasma cells }\end{array}$ \\
\hline Fibrosis & Not dense & Absent & Dense & Dense \\
\hline $\begin{array}{l}\text { Obliterative } \\
\text { phlebitis }\end{array}$ & - & - & - & + \\
\hline $\begin{array}{l}\text { SMALL BILE } \\
\text { DUCTS }\end{array}$ & & + & + & - \\
\hline $\begin{array}{l}\text { Onion skin } \\
\text { lesions }\end{array}$ & + & + & & \\
\hline
\end{tabular}

Table 2. Histopathologic features of bile ducts

\section{Liver biopsy}

Histological classification allows to score the disease in four stages (32). Stage 1 is characterized by portal oedema, mild portal inflammation, a non destructive cholangitis 
with infiltration of lymphocytes in the bile duct and ductular proliferation. In stage 2 (periportal stage) the lesion extends to involve periportal fibrosis. In stage 3 (septal stage) bridging fibrous septa develop and bile ducts degenerate and disappear. Stage 4 is characterized by cirrhosis.

Liver changes, however, may be patchy and there is a sampling variability.

\section{References}

[1] Maggi JR, Chapman RW. An update on primary sclerosing cholangitis. Curr Opin Gastroenterol 2008; 24: 377-383.

[2] Hirschfield GM, Heathcote EJ, Gershwin EE. Pathogenesis of cholestatic liver disease and therapeutic approaches. Gastroenterology 2010; 139: 1481-1496.

[3] Chapman R, Fevery J, Kalloo A, Nagorney DM, Boberg KM, Shneider B, et al. Diagnosis and management of primary sclerosing cholangitis. Hepatology 2010; 51: 660-678.

[4] Dave M, Elmunzer BJ, Dwamena BA, Higgins PD. Primary sclerosing cholangitis: metaanalysis of diagnostic performance of MR cholangiopancreatography. Radiology 2010; 256: 387-396.

[5] Burak KW, Angulo P, Lindor KD. Is there a role for liver biopsy in primary sclerosing cholangitis? Am J Gastroenterol 2003; 98: 1155-1158.

[6] Ponsionen CY, Vrouenraets SM, Prawirodirdjo W, Rajaram R, Rauws EA, Mulder CJ, et al. Natural history of primary sclerosing cholangitis and prognostic value of cholangiography in a Dutch population. Gut 2002; 51: 562-566.

[7] Ponsionen CY. Validation Endoscopy 2010; 42: 742-747.

[8] Bjornsson E, Olsson R, Bergquist A, Lindgren S, Braden B, Chapman RW, et al. The natural history of small-duct primary sclerosing cholangitis. Gastroenterology 2008; 134: 975-980.

[9] Bjornsson E, Boberg KM, Cullen S, Fleming K, Clausen OP, Fausa O, et al. Patients with small duct primary sclerosing cholangitis have a favourable long term prognosis. Gut 2002; 51: 731-735.

[10] Gregorio GV, PortmannB, Karani J, Harrison P, Donaldson PT, Vergani D, et al. Autoimmune hepatitis/sclerosing cholangitis overlap syndrome in childhood: a 16year prospective study. Hepatology 2001; 33: 544-553.

[11] Al-Chalabi T, Portmann BC, Bernal W, McFarlane IG, Heneghan MA. Autoimmune hepatitis overlap syndromes: an evaluation of treatment response, long-term outcome and survival. Aliment Pharmacol Ther 2008; 28: 209-220.

[12] Beuers U, Rust C. Overlap syndromes. Semin Liver Dis 2005; 25: 311-320.

[13] van Buuren HR, van Hoogstraten HJE, Terkivatan T, Schalm SW, Vleggaar FP. High prevalence of autoimmune hepatitis among patients with primary sclerosing cholangitis. J Hepatol 2000; 33: 543-548.

[14] Kaya M, Angulo P, Lindor KD. Overlap of autoimmune hepatitis and primary sclerosing cholangitis: an evaluation of a modified scoring system. J Hepatol 2000; 33: $537-542$.

[15] Floreani A, Rizzotto ER, Ferrara F, Carderi I, Caroli D, Blasone L, et al. Clinical course and out come of autoimmune epatiti/primary sclerosino cholangitis overlap syndrome. Am J Gastroenterol 2005; 100: 1516-1522. 
[16] Antoniazzi S, Cazzagon N, Egoue J, Lazzari R, Floreani A. The natural history of autoimmune hepatitis/primary sclerosing cholangitis (AIH/PSC) overlap syndrome. Digest Liver Dis 2010; 42, suppl.4: S312-S313 (Abstr).

[17] Mieli-Vergani G, Vergani D. Unique features of primary sclerosing cholangitis in children. Curr Opin Gastroenterol 2010; 26: 265-268.

[18] European Association for the Study of the Liver. EASL clinical practice guidelines: management of cholestatic liver diseases. J Hepatol 2009; 51: 237-267.

[19] Batres LA, Russo P, Mathews M, Piccoli DA, Chuang E, Ruchelli E. Primary sclerosing cholangitis in children: a histologic follow-up study. Pediatr Dev Pathol 2005; 8: 568-576.

[20] Ghazale A, Chari ST, Zhag L, Smyrk TC, Takahashi N, Levy MJ, et al. Immunoglobulin G4-associated cholangitis: clinical profile and response to therapy. Gastroenterology 2008; 134: 706-715.

[21] Etemad B, Whitcomb DC. Chronic pancreatitis: diagnosis, classification, and new genetic developments. Gastroenterology 2001; 120: 682-707.

[22] Kamisawa T. IgG4-positive plasma cells specifically infiltrate various organs in autoimmune pancreatitis. Pancreas 2004; 29: 167-168.

[23] Mendes FD, Jorgensen R, Keach J, Katzmann JA, Smyrk T, Donlinger J, et al. Elevated serum IgG4 concentration in patients with primary sclerosing cholangitis. Am J Gastroenterol 2006; 101: 2070-2075.

[24] Zen Y, Fujii T, Harada K, et al. Th2 and regulatory immune reactions are increased in immunoglobulin G4-related sclerosing pancreatitis and cholangitis. Hepatology 2007; 45: 1538-1546.

[25] Nishimori I, Otsuki M. Autoimmune pancreatitis and IgG4-associated sclerosing cholangitis. Best Pract Res Clin Gastroenterol 2009; 23: 11-23.

[26] Nakazawa T, Ando T, Hayashi K, Naitoh I, Ohara H, Joh T. Diagnostic procedures for IgG4-related sclerosing cholangitis. J Hepatobiliary Pancreat Sci 2010;

[27] Rudolph G, Gotthardt D, Kloeters-Plachky P, Kulaksiz H, Stiehl A. In PSC with dominant bile duct stenosis, IBD is associated with an increase in carcinomas and reduced survival. J Hepatol 2010; 53; 313-317.

[28] Kamisawa T, Takuma K, Anjiki H, Egawa N, Kurata M, Honda G, et al. Sclerosing cholangitis associated with autoimmune pancreatitis differs from primary sclerosing cholangitis. World J Gastreonterol 2009; 21: 2357-2360.

[29] Zen Y, Harada K, Sasaki M, Sato Y, Tsuneyama K, Haratake J, et al. IgG4-related sclerosing cholangitis with and without inflammatory pseudotumor, and sclerosing pancreatitis-associated sclerosing cholangitis: do they belong to a spectrum of sclerosing pancreatitis? Am J Surg Pathol 2004; 28: 1193-1203.

[30] Zhang L, Notohara K, Levy MJ, et al. IgG4-positive plasma cell infiltration in the diagnosis of autoimmune pancreatitis. Mod Pathol 2007; 20: 23-28.

[31] Karlsen TH, Schrumpf E, Boberg KM. Primary sclerosing cholangitis. Best Pract Res Clin Gastroenterol 2010; 24: 655-666.

[32] Ludwig J. Surgical pathology of the syndrome of primary sclerosing cholangitis. Am J Surg Pathol 1989; 13, suppl.1: 43-49. 


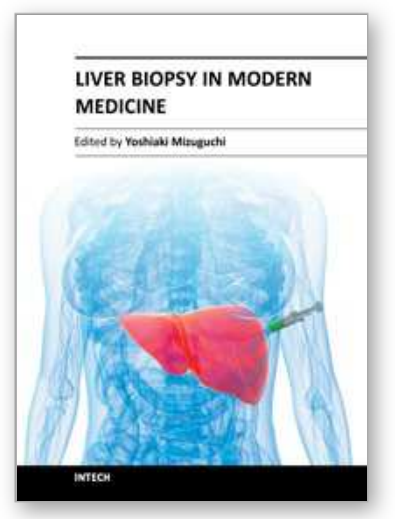

\author{
Liver Biopsy in Modern Medicine \\ Edited by Dr. Yoshiaki Mizuguchi
}

ISBN 978-953-307-883-0

Hard cover, 378 pages

Publisher InTech

Published online 10, October, 2011

Published in print edition October, 2011

Liver biopsy, first performed by Paul Ehrlich in 1883, remains an important diagnostic procedure for the management of hepatobiliary disorders and the candidate/donated organ for transplantation. The book "Liver biopsy in Modern Medicine" comprises 21 chapters covering the various aspects of the biopsy procedure in detail and provides an up-to-date insightful coverage to the recent advances in the management of the various disorders with liver biospy. This book will keep up with cutting edge understanding of liver biopsy to many clinicians, physicians, scientists, pharmaceutics, engineers and other experts in a wide variety of different disciplines.

\title{
How to reference
}

In order to correctly reference this scholarly work, feel free to copy and paste the following:

Annarosa Floreani (2011). Clinical Variants of Primary Sclerosing Cholangitis: When Does Liver Biopsy Make the Diagnosis?, Liver Biopsy in Modern Medicine, Dr. Yoshiaki Mizuguchi (Ed.), ISBN: 978-953-307-883-0, InTech, Available from: http://www.intechopen.com/books/liver-biopsy-in-modern-medicine/clinical-variants-ofprimary-sclerosing-cholangitis-when-does-liver-biopsy-make-the-diagnosis-

\section{INTECH}

open science | open minds

\section{InTech Europe}

University Campus STeP Ri Slavka Krautzeka 83/A 51000 Rijeka, Croatia Phone: +385 (51) 770447

Fax: +385 (51) 686166 www.intechopen.com

\section{InTech China}

Unit 405, Office Block, Hotel Equatorial Shanghai No.65, Yan An Road (West), Shanghai, 200040, China 中国上海市延安西路65号上海国际贵都大饭店办公楼 405 单元 Phone: +86-21-62489820

Fax: $+86-21-62489821$ 
(C) 2011 The Author(s). Licensee IntechOpen. This is an open access article distributed under the terms of the Creative Commons Attribution 3.0 License, which permits unrestricted use, distribution, and reproduction in any medium, provided the original work is properly cited. 